\title{
MARKETING STRATEGIES FOR ORGANIC RESTAURANT IN UBUD TOURIST AREA - BALI
}

\author{
Ni Putu Ariesta Budiani, Ni Luh Suastuti, Lidjah Magdalena Massenga. \\ Bali Tourism Institute, Nusa Dua. \\ ariestabud@gmail.com
}

\begin{abstract}
Public awareness of the importance of adopting a healthy lifestyle continues to increase. One indicator can be seen is an increase in the consumption of organic food. Likewise, the high interest of the global community in organic food is expected to impact on the restaurant business in Bali, especially in Ubud Tourist Area. At this time there are some marketing difficulties facing the restaurant business that sells food made from organic.

The purpose of research is exploring the strengths, weaknesses, opportunities, and threats organic restaurant in Ubud Tourist Area Bali. It is also to investigate the marketing strategy to increase tourists visiting an organic restaurant in Region Ubud - Bali.

Methods of data collection using observation, interviews, questionnaires, and documentation, and then analyzed using SWOT analysis. The results of this study are the internal condition of organic restaurants in Ubud Tourist Area is excellent for tourists and managers of restaurants, as well as external environmental conditions in Ubud. Based on a combination of analysis and IE Matrix Matrix position, the right strategy is applied industry Organic restaurant in Ubud Tourist Area is a strategy of market penetration, product development, and market development is limited.
\end{abstract}

Keywords: marketing strategy, organic restaurant, a tourism area

\section{Introduction}

Lately in the big cities in Indonesia is growing rapidly issues plastic rice and rice contaminated with harmful preservatives. The impact of this issue is the reduction in the number of sales turnover of non - organic rice and the rice or increase in demand for organic agricultural products. Healthy lifestyle is now the trend for the middle and upper classes throughout the world. Public awareness of the importance of adopting a healthy lifestyle is increasing from time to time. One indicator that can be seen is an increase in the consumption of organic food . Consuming organic food can serve as a cleanser of toxins - toxins in the human body ( antioxidant ) organic foods provide nutrients to the body, activate cells the cells of the body and also at the same time maintaining the balance of health ( Kartini , 2011) .

The high demand for organic food is increasing the number of organic farms in the world. In the Asian region, the country with the largest organic farms are 
India and China. (Pranasari 2004, November). In 1998, according to a survey conducted in Europe found that $94 \%$ of respondents buy organic products because they are very concerned with the health of themselves and their family members (Eureka Indonesia Foundation website, 2009). Organic food is becoming one of the business communities in preserving the environment, because the food does not use materials - hazardous materials such as pesticides. Consuming organic food has been believed by the world community can support the preservation of the environment and contribute to reducing global warming. This opinion is supported by Davis, (2006: 1), which states: "This rapid growth of organic food industry may be traced to Increased consumer confidence in organic foods, such as well as to concerns about possible health risks and environmental impacts of conventional food production methods. ". With the awareness that it is expected that companies can implement environmental issues as one of their marketing strategy ( green marketing ) .

Bali island whose economy is driven by agriculture and tourism, has a huge potential to combine or synergize agriculture ( organic ) products are made from organic restaurant. Synergies are agriculture and tourism potential to encourage local people and tourists to enjoy organic food products that are environmentally friendly . Likewise, the high interest of the global community in organic food, is expected to impact on the restaurant business in Bali, Ubud Tourist Area .

Based on data from the Department of Tourism Gianyar, Ubud has many established restaurants that sell organic food so that there are substantial opportunities for businesses in the field of organic food, to the efforts in this area needs to be organized, both in terms of product quality, hygiene, food safety, packaging, promotion and marketing, so that the organic food products sold for the better and in the end can give satisfaction to tourists . Growing awareness of travelers to eat healthy foods produced from chemical-free agriculture should directly or indirectly support the growing number of organic restaurants and organic food consumption at Ubud .

At this time there are some marketing difficulties faced by the restaurant business that sells food made from organic, among other things : the price of the material is more expensive, material size smaller, yet all travelers aware of the importance of healthy food free of chemicals and genetic engineering, and trends travelers who are sensitive to price changes. The impact is the difficulty restaurant market products in an effort to attract new market segments in addition to broader segments of the market which has been a loyal customer of an organic restaurant. For that it would need to be held research on organic restaurant marketing strategies, especially in considering Ubud area is already known as one of the regions which have long offered organic food as one of its appeal .

The purpose of this study can be divided into three parts .First, this study aims to explore the strengths and weaknesses of organic restaurants in Region Ubud - Bali . Second, this study aims to explore the opportunities and threats organic restaurant in Region PatiwisataUbud - Bali . And third, the study aims to investigate the right marketing strategy to increase tourists to visit an organic restaurant in Region Ubud - Bali . The results of this study are expected to be a referral to the stakeholders, especially those working in the restaurant business in Bali . 


\section{Literature Review}

Research conducted by Sangkumchaliang and Huang (2012 ) entitled " Consumers ' Perceptions and Attitudes of Organic Food Products in Northern Thailand. " Indicates that the respondent's main motivation for buying organic food products are organic food products healthier and more environmentally friendly. Buyers of organic food products are usually old and older and have a background in higher education. The main obstacle in the sales of organic food products is the availability of information and awareness of consumers themselves.

Research conducted by Suastuti, et al ( 2014 ) entitled perception of foreign tourists towards organic food in Ubud Tourist Area found that the perception of foreign tourists towards organic food in ubud in general it can be concluded very well . If seen from the analysis results for the five variables organic food, there are two variables that got the lowest score is the variable perception of the quality of organic food gets a mean value of 4.12 ( there are at the level of the answers agree / well ) and variable perceptions about the price of organic food gets a mean value 4.00 ( there are at the level of the answers agree / well ). Although these two variables have got good perception still needs to be held mainly on the improvement of food quality and price, especially value for money so that later the perception of foreign tourists towards organic food to be better .

Risyamuka and Mandala ( 2014 ) concluded that the variable product, promotion, price, and the place has a simultaneous effect on the consumer's decision to buy organic food products in Restaurants Sari OrganikUbud . Furthermore , Risyamuka and Mandala in journals , entitled Influence Buying Decision Against Green Marketing Green Products in Restaurants Sari OrganikUbud found that the variable product, promotion, price and place has a positive and significant influence partially on green product purchasing decisions at the restaurant.

Lai and Rivera (1990) case study uses an analytical framework for assessing a marketing strategy for a destination development project called "Temple Town Lake Project". In this case study analyzed the internal factors that are strengths and weaknesses and external factors that are the opportunities and threats in the development of this project. The internal factors consist of Price, Product (whether tangible or services), Promotion (sales and advertising), Place (distribution system / network), Employee (functional departments) and Competitive Advantage (trademark, relations with relationships). While external factors are identified in detail as follows: (1) Competitive Environment is a variety of products or services which may be a substitute; (2) Demographic trends consist of changes in population characteristics, changes in the American family system like little children, single parents, better education levels in the population, the increasing ethnic and racial differences; (3) Economic trends consist of changes in the personal income and changes in consumer purchasing patterns; (4) Natural Environment consists of a shortage of raw materials; the increase in energy costs; rising levels of pollution; and government intervention in the management of natural resources; (5) Technology trends consist of technological changes more rapidly, presenting opportunities are unlimited, high-level research and development budget, the concentration on a limited development, and increasing government regulation. (6) Political trends consist of business 
regulatory legislation and the growth of public groups with a specific purpose. (7) Cultural trends consist of strong cultural values; the existence of sub-cultures; a shift in cultural values both. (7) publics made up of public finances and public media.

Research Ahmad ,Siti M.B. (2010) with the title of Organic Food : A Study of Demographic Characteristics and Factors Influencing Purchase Intention Among Consumers in Klang Valley, Malaysia found that the purchase intention of organic products is strongly influenced by consumers' perceptions of the value of purchases of organic products as well as confidence in the safety and health of products organic .

\section{Methodology}

Data was collected through observational surveys, interviews (interview), distributing questionnaires (questionnaires), and documentation study.

In accordance with a model designed research, there are several variables that are identified. Several variables were identified and analyzed further in the internal environment are the variables concerning the marketing mix or the Marketing Mix - The Four Ps consisting of Place / Location, Product, Price and Promotion (Walker, 2008: 118-133). Place / location consists of indicators visibility, easy access, convenience, curbside appeal, and parking. Product consists of indicators excellent food, good service, cleanliness, ambiance. Price consists of the indicator value for money, credit card acceptance, and competitors price. Promotion consists of indicators of advertising, in-house advertising, advertising appeals, travel guide for free advertising, yellow page advertising, and mailing list. Meanwhile, opportunities and threats, or external factors that become variables in this study were Macroenvironment forces (demographic-economic, technological, political-legal, socio-cultural) and Microenvirontment forces (customers, competitors, distribution channels, supplies) in Kotler, Bowen, Makes (2010: 73).

In order to determine a marketing strategy to operations of restaurants and homes required an analysis of the factors that are strengths and weaknesses and the opportunities and threats that are owned by the restaurants and eating houses .

There are four concepts in determining the marketing strategy formulation in relation to the management of new products and existing products in existing markets and new markets, namely the market penetration strategy, product development strategy, market development strategy, and the strategy of diversification .

\section{Data Analysis Techniques .}

Expected outcomes analysis was used to obtain the final value of the classification of the position of each indicator in this study. Value analysis classification classified into four criteria as shown in Table 3.1 . 
Table 3.1 Analysis Result Catagory

\begin{tabular}{ccc}
\hline Nilai & Range & Result \\
\hline 4 & $3,26-4$ & Excellent \\
3 & $2,51-3,25$ & Good \\
2 & $1,76-2,50$ & Fair \\
1 & $1,00-1,75$ & Poor \\
\hline
\end{tabular}

Source: Arcana, 2008:97

Internal - External Matrix positioning the various divisions of the organization in view of nine cells. David, (2006 : 300-304 ) states that the Internal- External Matrix is based on two key dimensions : total weighted average Internal Factor Evaluation ( IFE ) on the $\mathrm{x}$ axis and the total weighted average of External Factor Evaluation ( EFE ) on the y axis.

SWOT analysis aims to determine the strengths, weaknesses that are affected by the company's internal policies and the opportunities and threats that are influenced by external factors that can not be controlled by the company. SWOT analysis is a tool to analyze the situation, which if done correctly it will generate a strong foundation for the formulation and formulating a strategy ( Bozac and Tipuric , 2006) .

To answer the problem formulation which has been described previously, this study requires primary data obtained through a questionnaire. This research deploy two types of questionnaires, the questionnaire distributed to consumers organic restaurant ( to obtain indicators of the strength and weaknesses of the internal environment of marketing ) and a questionnaire distributed to managers organic restaurant ( to obtain indicators of the opportunities and challenges of the external environment of marketing ) in Region Tourism Ubud, Gianyar.

To obtain the data indicator of the strengths and weaknesses marketing environment, this study adopts the 4 Ps of the marketing mix concepts in the restaurant industry proposed by Walker ( 2008 : 118-133) which consists of : product (excellent food, good service, value, ambiance), price ( value for money, credit card acceptance, competitors price), promotion (advertising, inhouse advertising, advertising appeals, travel guide for free advertising, yellow page advertising, mailing list ), and place ( visibility, easy access , convenience, curbside appeal, parking) .

To obtain indicators of the external environment of marketing, this study adopts the theory Kotler, et al (2010: 73 ) combined with issues of environmental sustainability and protection of spatial raised by Lai and Rivera (1990), Cousin, et al ., (2002; 15 ), Morrison ( 2002 ), Bozak and Tipuric , ( 2006 ).

The external environment of marketing in this study consisted of variables : 1 ) competition ; 2 ) demographic - economic ( of asian tourist boom to Ubud, growth of hotel and lodging industry in Ubud, consumers expenditure pattern) ; 3 ) technological ( advant culinary / cooking technology, marketing advant technology / media ) ; 4 ) political - legal (regional political tension, local government regulation, security area of Ubud and beyond ) ; 5 ) social- cultural (local community, local value and culture) ; 6 ) customers (local customers, domestic and foreign customers) ; 7 ) distribution channels (travel agents, shuttle and taxi drivers, free individual / group traveler) ; 8 ) supplies (supply of clean 
fresh waters , supply of energy / electricity, supply of fresh raw materials ) ; 9 ) natural environment ( environtment carrying capacity, polution level) .

Internal Factor Evaluation ( IFE ) and External Factor Evaluation ( EFE ) will be calculated to obtain the value of Internal - External ( IE ) Matrix or Position Matrix ( Matrix positions) . Furthermore, based on the value of Matrix Position the SWOT analysis can be formulated or conceptualized to acquire Key Strategies ( Grand Strategies ) and Strategic Alternative (Alternative Strategies ).

\section{Result and Discussion}

Strengths and Weaknesses

Based on the above data processing techniques showed that the variables become a force for the internal environment of the restaurant industry marketing in Ubud Tourist Area can be seen in Table 4.1

\section{Table 4.1}

Variables of strengths and weaknesses Marketing Industry Restaurants At Region Tourism Ubud

\begin{tabular}{lcc}
\hline \multicolumn{1}{c}{ Variabel } & Bobot & Mean \\
\hline & & \\
Excellence Organik Food & 0.085 & 3.61 \\
Good Service & 0.085 & 3.65 \\
Cleanliness & 0.085 & 3.44 \\
Ambiance & 0.060 & 3.47 \\
Visibility & 0.025 & 3.37 \\
Easy access & 0.025 & 3.37 \\
Convience & 0.060 & 3.34 \\
Curbside appeal & 0.020 & 3.19 \\
Parking & 0.035 & 2.93 \\
. Healthy food \& beverages for money & 0.076 & 3.54 \\
. Credit card acceptance & 0.015 & 2.89 \\
. Competitor price & 0.065 & 3.23 \\
. Green consumerism advertising & 0.058 & 3.16 \\
. In house advertising & 0.054 & 2.99 \\
Advertising appeal & 0.057 & 2.96 \\
Travel guide for free advertising & 0.065 & 2.79 \\
. Social media advertising & 0.065 & 2.94 \\
. Mailing list & 0.065 & 2.61 \\
\end{tabular}

Resoucer :the data processing

Based on the description in the above table, there is no variable that is a weakness of organic restaurants when seen from value - average ( mean) feedback rating. This is certainly the conditions are good and should be maintained. But when viewed in more detail in Table 4.1 , it can be said that some variables still scored quite low as a variable parking, credit card acceptance, in house advertising, advertising appeal, travel guide advertising, social media advertising , and mailing list. Some of these variables are a concern for the parties manage to increase sales in the organic restaurant. This is also supported by the 
results of the evaluation of the internal factors of industry marketing organic restaurant in Ubud Tourist Area .

Based on the obtained data processing that no variables that are a threat to industry organic restaurant in Ubud . It must have been very good because it means the external aspects in Ubud all support organic restaurant business.

Internal - External Matrix Analysis and SWOT Analysis Diagram Analysis ( position matrix) ) Enterprises Organic Food Restaurant in Ubud Tourist Area .

a. Internal - External Analysis Matrix ( Matrix IE )

Based on the analysis of the factors or environmental aspects of internal and external environment industry marketing organic restaurant in Ubud Tourist Area , then obtained a total score of internal marketing factors worth 3.4993 points and a total score of external factors marketing worth 3.3455 points. The position of the internal environment of marketing ( score 3.4993 ) and the external environment of marketing ( score 3.3455 ) restaurants are known to use the Internal - External Matrix in

TOTAL VALUE WEIGHTED AVERAGE IFE

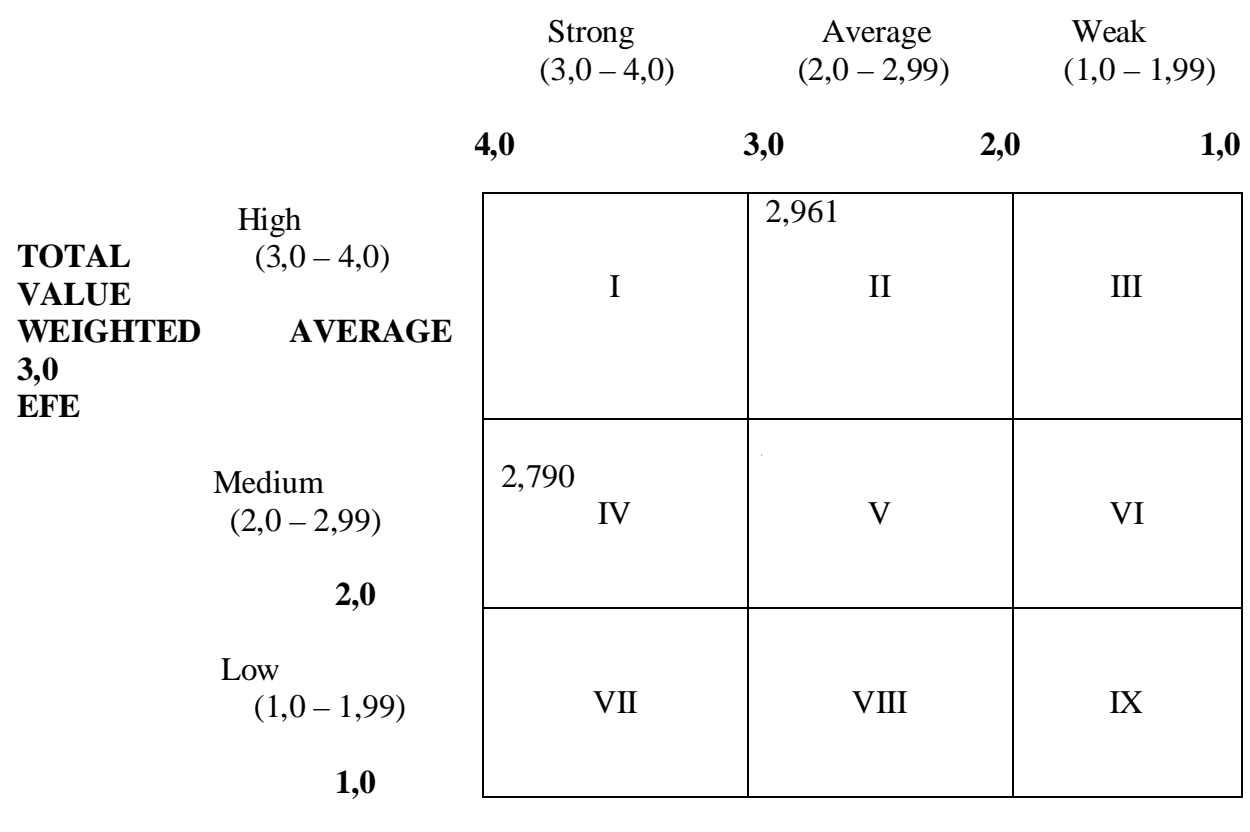

Figure 2.Internal-External Matrix Position Matrix Organic Restaurant in Ubud Tourist Area

Based Internal- External Matrix can be seen that the position of industry Organic Restaurant in Ubud Tourist Area is in cell I. Because of the position of the restaurant industry is in cell I, based on the theory of David (2006:302), the strategy that should be implemented by the restaurant industry in Region Tourism 
Ubud is a " Hold and Maintain strategy" or the strategy of " Keep and Maintain " consisting of market penetration strategies and product development strategy, market development, and integration to the fore.

b. SWOT Analysis Diagram ( Matrix Position )

To obtain the industry's position is based on the theory of Hsu and Powers (2002 ) then calculated the difference between internal score (strength weaknesses ) and external difference score ( odds - the threat of ) the restaurant industry. Based on the data obtained by the differences of scores of internal and external difference scores restaurant industry in Ubud Tourist Area as follows:

Difference internal score $: 3.4993-0=3.4993$

Difference external score : 3.3455 - $0=3.3455$

Based on the difference value, then the position of the restaurant industry can be determined with a SWOT Analysis Diagram as follows :and external difference scores restaurant industry in Ubud Tourist Area as follows :

$(+)$

The main opportunities

Of the environment

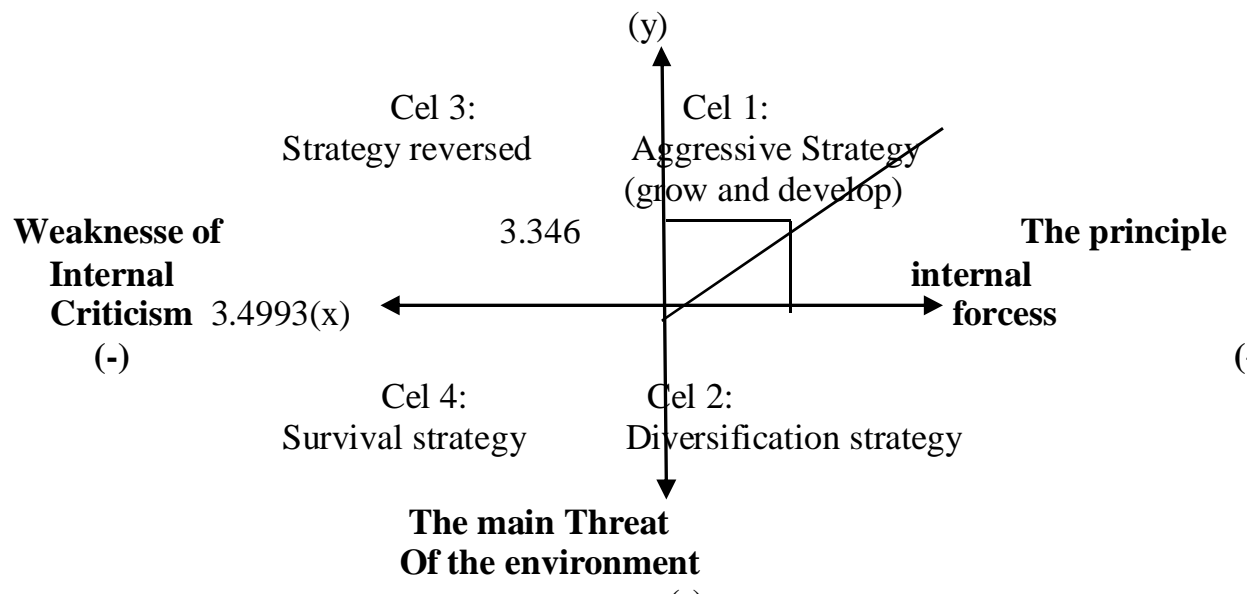

$(-)$

\section{Figure 3. SWOT Analysis Diagram /Position Matrixof Organic Restaurant At Ubud Region}

Based Diagram SWOT Matrix restaurant industry in Region Tourism Ubud is in quadrant I, therefore, the right strategy is applied is "Growth and Build Strategy" or the strategy of " Grow and Develop " consisting of market penetration strategies, market development strategy, and strategy development product. In this position, the organic restaurant industry can take risks aggressively if needed .

To combine the results of the analysis based on the theory of David (2006 : 301 ) which is a strategy of market penetration and product development with the results of the analysis based on the theory Hsu and Powers (2002:133) which is a strategy of market penetration, market development, and product development strategy, the right strategy applied is a market penetration strategy, product development strategy, and market development strategy on a limited basis . 


\section{Conclusion}

Based on the analysis and discussion described earlier, then delivered the following conclusions :

1. Of the 18 internal factors, all of these indicators is the power of Organic restaurant in Ubud. This condition is very good for the tourist and restaurant management. This condition desired by the traveler and the manager of the restaurant .

2. For the thirteenth external factors, all the marketing opportunities in the organic restaurant industry. This indicates that all the conditions of the external environment in Ubud has been supporting efforts Organic Restaurant . This is certainly not surprising because Ubud has been known to have some place organic farming and also packages - packages normally yoga class yoga participants is also an organic food lovers .

3. Based on a combination of analysis and IE Matrix position, the right strategy is applied for the restaurant industry Organic in Ubud Tourist Area is a market penetration strategy, product development strategy, and market development strategy on a limited basis . Relevant alternative strategies to be applied in favor of the main strategies are complementary strategies reception facilities payment by credit card so that makes it easy for tourists to pay. Increase media campaign by increasing the use of social media , mailing lists, and travel guide as a media

\section{REFERENCES}

Ahmad, S. N. B. 2010. Organic food : A Study On Demographic Characteristic and Factors Influencing Purchase Intentions Among Consumers in Klang Valley, Malaysia. International Journal of Business and Management.Vol. 5, no. 2.

Amalina, N. 2010. User Perceptions Of Organic Food in Kota Kinabalu (Thesis). University Malaysia Sabah.

Celik, N. 2009. Strategy making with quantified SWOT Approach; A case analysis on tourism industry in Black Sea Region of Turkey. Zonguldak Karaelmas University, Turkey. Departmen of Business Administration.

Kotler, P., Bowen, J.T., Makens, J.C. 2010. Marketing for Hospitality and Tourism. Fifth Edition. Pearson. New Jersey, USA.

Miandehi, P.M, and Masrouri, M.Y. 2013. Assesment of SWOT Model on Tourism Industry in Sustainable Development of Rural Areas: case Study on Bandar-E Anzali. World Applied Sciences Journal 21 (3): 455-464, 2013. ISSN 1818-4952. 
Pahl,N. and Richter, A. 2009. SWOT Analysis-idea, methodology and practical approach. GRIN Verlag.

Pearce II, J.A., and Robinson, R.B. (2011). Strategic Management: Formulation, Implementation, and Control. Twelfth Edition. Mcgraw-Hill/Irwin. New York, USA.

Risyamuka, I K. Dan Mandala, K. 2014. Pengaruh Green Marketing Terhadap Keputusan Pembelian Produk Hijau di Restoran Organik, Ubud. Fakultas Ekonomi dan Bisnis Universitas Udayana, Bali, Indonesia.

Risky, K.S. 2013. " penerapan Green Marketing pada Bisnis Produk Kosmetik: Jurnal JIBEKA Volume 7, No. 3 Agustus 2013: 47-53.

Sangkumchaliang, P and Huang, W. C. 2012. Consumer's, Perceptions and Attitudes of Organic Product in Northerm Thailand. International Food and Agribusiness Management Review. Vol. 15, Issue 1.

Suastuti,dkk. 2014, “Persepsi Wisatawan mancanegara Terhadap Makanan Organik di Kawasan Pariwisata Ubud”, Insyima (Prociding).

Varadarajan, R. (2010). Strategic marketing and marketing strategy : domain, definition, fundamental issues and foundational premises. Journal of Academic Marketing Science, (2010) 38: 119-40. DOI 10.1007/s1174-0090176-7. 